\title{
Development and management of groundwater in Eritrea, N-E Africa
}

\author{
K. Vasudevu \\ Lecturer, Dept. Civil \& Environ. Engg., University of West Indies, St. Augustine, Trinidad \& Tobago \\ vasudevu.kanithi@sta.uwi.edu
}

Abstract: The water needs of Eritrea are almost entirely met from groundwater resources. Except the reservoirs of the cities of Asmara and Mendefera there are no surface water resources in the country. The Setit is the only perennial river traversing a small southwestern tract of the country. The available water resources hardly cater to around $15 \%$ of the requirement of the people. In the present situation only groundwater development and management is the viable solution. The geology of the area, including the basement rocks is suitable as receptacles of groundwater. Besides, the country is crisscrossed by many shears, fractures, normal faults, extension joints and dykes which act as conduits. As a part of groundwater management, aforestation, social forestry, horticulture and grasslands are to be promoted extensively, initially in the central high land zone and the green belt zone that receive more than $800 \mathrm{~mm}$ rainfall. The same programs are to be extended, step - by - step to the western escarpment, southern lowland, northwestern low land and the coastal zone, which wears a desert look. Both surface and subsurface water development and management are essential to meet the water requirements of the country and to avoid soil erosion and associated problems.

Keywords: Eritrea, groundwater resource management.

Introduction

Eritrea is one of the youngest countries which gained freedom in recent decades (about a decade and half ago) after a prolonged war of 30 years (Ravinder Rena, 2007). The economy is agrarian. It is a small country located in the horn of Africa $\left(11.5-17^{0} \mathrm{~N}\right.$ latitudes and $36.5-43.5^{\circ} \mathrm{E}$ longitudes). It is bordered by Ethiopia in the south, Sudan in the west, the Republic of Djibouti in the southeastern part and the Red Sea in the east. It has a total area of $124,000 \mathrm{sq}$. $\mathrm{km}$, a coastline of $1060 \mathrm{~km}$ and more than 350 islands in the Red Sea (Gajendran, 2007a).

The population of Eritrea is approximately 3.5 million with a growth rate of more than $3 \%$. Though the population density is 28 per sq $\mathrm{km}, 65 \%$ of it lives in the high land and green belt zones which amount to only $16 \%$ of the total area. The concentration of population in the high lands is due to several factors, including better agricultural production and high incidence of malaria in the low land areas. The cultivable land is about 1.6 million hectares accounting for $13 \%$ of the total area.
Agriculture is an important sector of Eritrea's economy. Nearly all crop and livestock production is based on smallholder of traditional agriculture characterized by subsistence orientation and low productivity. Reports (Project on Strengthening of Agricultural Research in Eritrea) reveal that it was having trade with Saudi Arabia and some European countries in vegetables and meat export before the war for independence started. Its economy, particularly agricultural was seriously affected by its prolonged war, displacement of people and periodic droughts. Crop production and livestock numbers fell by one half and one third respectively during the 80 s. Since 1993, it has been building its public sector institutions and establishing government policies and strategies for development especially on educational reconstruction (Gajendran, 2007b). Considerable development occurred between 1993 and 1998. But the conflict with Ethiopia erupted in 1998 and it caused disruption of production in all sectors. Today the nation's economy improves only when the rural economy based on horticulture and cattle breeding flourishes. Water resources are more important for the sustenance and growth of rural economy. At present, rainfall is the only source of water.

The climate

The climate in Eritrea ranges from hot arid in the coastal plain to temperate sub humid in isolated micro catchments within the eastern highland escarpment area. Altitude is the major factor in determining the temperature and rainfall. The minimum and maximum mean annual temperatures are $3^{\circ}$ and $28^{\circ} \mathrm{C}$ in the highland and $20^{\circ}$ and $48^{\circ} \mathrm{C}$ in the lowlands (Water Resource Department data base).

Geological Setting

The general geology of Eritrea is shown in the Fig.1. Eritrea, a Precambrian terrain is a part of the Arabian- Nubian Shield that extends from Saudi Arabia and Egypt in the north through Eritrea, Ethiopia and Sudan to Somalia, Kenya and Uganda in the south. The Arabian -Nubian Shield consists dominantly of low-grade volcano sedimentary-ophiolite assemblies, granites and gneisses (Vail, 1987). The Mozambique Belt (Holmes, 1951) extents from Mozambique to Ethiopia and into Eritrea in a N-S trending zone of high-grade gneisses and migmatites with folded schists, marbles and amphibolites intruded by granites. These two, the Arabian-Nubian Shield 
and the Mozambique Belt form an important orogenic belt in Africa extending from Egypt to Mozambique and Madagascar. As both experienced similar tectonic history since at least $1100 \mathrm{Ma}$, the term Pan-African has been applied for both the orogenic belts (Berhe, 1991).

In Eritrea, the Precambrian basement complex outcrops in most parts of the country. These rocks have been subjected to varying degrees of metamorphism (low and high grade) and are generally folded and foliated. The younger Mesozoic sand Tertiary sediments and volcanic sequences lie unconformable on the eroded and lateritised surfaces of the Precambrian basement in the southern part of the central highland and Danakil areas where lime stones and sand stones predominate. Igneous activity associated with the Red Sea rift system gave rise to the accumulation of significant sequences of volcanic materials in many parts of the country. Recent sediments comprising alluvial deposits, alluvial fans, colluviums and sand dunes occur throughout the country, but are well developed in the eastern and western low lands.

Generally the Geology of the country consists of Proterozoic low to high grade metamorphic rocks and the associated intrusives (60\%), Tertiary-Quaternary volcanics (15\%) and consolidated to unconsolidated sediments (25\%). But the basement metamorphics and associative intrusives are highly foliated. They also have several normal faults in them (Zerai, 1996; Krishna Rao, 2007).

Rainfall

Rainfall is the main entity of the hydrological cycle. It is important in renewing the water resources, including subsurface water bearing formations. It is torrential and of high intensity over a short duration, very unpredictable and occurs sporadically. It varies temporally and spatially. The rainfall values for the different agro ecological zones of the country indicate that the normal average rainfall varies from $200 \mathrm{~mm}$ in the coastal plains up to $1000 \mathrm{~mm}$ in the green belt zone. Owing to the rugged nature of the high lands, lack of

Table1. The normal average rainfall in Eritrea

\begin{tabular}{|l|l|}
\hline Agro-ecological zone & $\begin{array}{c}\text { Normal average } \\
\text { rain } \\
(\mathrm{mm})\end{array}$ \\
\hline The central highland (CHZ) & $400-700$ \\
\hline The green belt (GBZ) & $700-1000$ \\
\hline The western escarpment (WEZ) & $600-700$ \\
\hline $\begin{array}{l}\text { The southwestern lowland } \\
\text { (SWLZ) }\end{array}$ & 400 \\
\hline $\begin{array}{l}\text { The northwestern lowlands } \\
\text { (NWLZ) }\end{array}$ & 300 \\
\hline The coastal plains (CPZ) & 200 \\
\hline
\end{tabular}

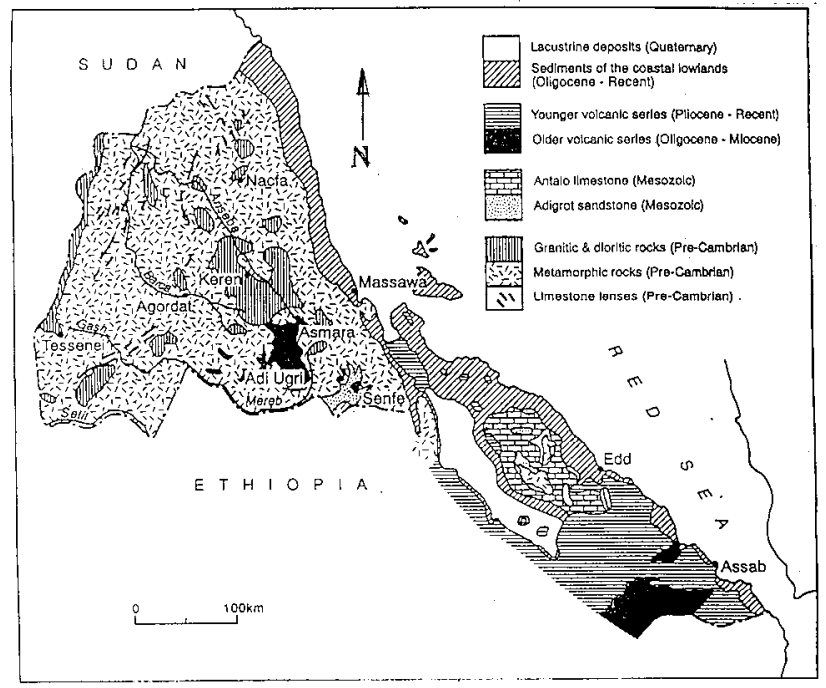

Figure 1: Geological map of Eritrea (after Abul Haggag 1961)
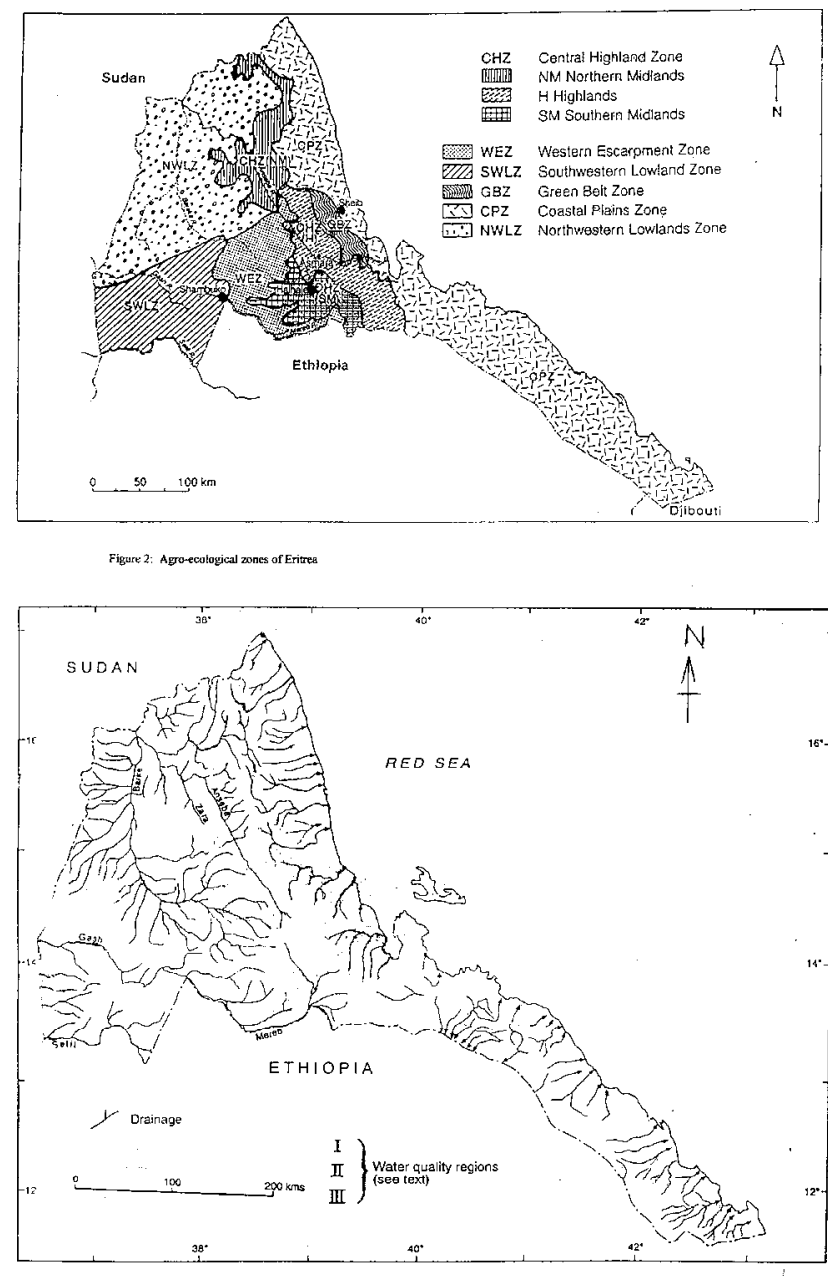

Figure 3: Map of Eritrea shwowing details of surface hydrotogy

grass cover and largely deforested terrains, most of the rain develops into flash floods causing severe soil erosion.

Eritrea experiences two rainy seasons locally known as 'Kiremti' (frequent and long rainy season 
Table 2. Examples of bore well (bw) data in all aquifer systems (source: WRD, Ministry of Land, Water and Environment, Government of Eritrea)

\begin{tabular}{|c|c|c|c|c|c|}
\hline Location of bw & No. of bw & Depth in $\mathrm{mm}$ & Aquifer lithology & Yields in $1 / \mathrm{s}$ & $\begin{array}{l}\text { Hydrogeological } \\
\text { regions }\end{array}$ \\
\hline Omhajer & 2 & 35,40 & Alluvial and granite & $0.15,6$ & Setit \\
\hline Sheshebit & 2 & 41,50 & $\begin{array}{l}\text { Fractured } \\
\text { metasediment }\end{array}$ & $2,1.5$ & Setit \\
\hline Dechinema & 1 & & Marble & 2 & Setit \\
\hline Golige & 1 & 43 & Granite & 2 & $\begin{array}{l}\text { Omhajer- } \\
\text { Tesenei Plain }\end{array}$ \\
\hline Tesenei & 2 & 32,26 & $\begin{array}{l}\text { Alluvial, Fractured } \\
\text { granite }\end{array}$ & $3.6,10$ & Lower Gash \\
\hline Haikota & 2 & 49,38 & Granite & $2.5,2.5$ & Lower Gash \\
\hline Barentu & 1 & 36 & Fractured Granite & 2 & Mereb-Gash \\
\hline Adobha (Baden) & 4 & $51,39,78$ & $\begin{array}{l}\text { Alluvial, Fractured } \\
\text { Granite }\end{array}$ & $1.2,5,8,10$ & Anseba-Barka \\
\hline $\begin{array}{l}\text { Gogne } \\
\text { (Mogoraib) }\end{array}$ & 2 & 30,50 & $\begin{array}{l}\text { Alluvial, Fractured } \\
\text { Marble }\end{array}$ & $>10$,dry & Anseba-Barka \\
\hline Agordet & 1 & 31 & Alluvial & 6 & Anseba-Barka \\
\hline Adi Ibrihim & 1 & 30 & Alluvial, Marble & 2.2 & Anseba-Barka \\
\hline $\begin{array}{l}\text { Mogoraib- } \\
\text { BarkaRiver Jn. }\end{array}$ & 6 & 30,45 & Alluvial & 4,15 & Anseba-Barka \\
\hline $\begin{array}{l}\text { Mogoraib } \\
\text { (lower) }\end{array}$ & 3 & $40,45,45$ & $\begin{array}{l}\text { Alluvial + fracture } \\
\text { zone }\end{array}$ & $8,4.4,2$ & Anseba-Barka \\
\hline Keru & 3 & 41,40 & $\begin{array}{l}\text { Basement rock } \\
\text { (gneiss) }\end{array}$ & 2,1 & Anseba-Barka \\
\hline Hawashait & 2 & 40,31 & Alluvial & 2,15 & Anseba-Barka \\
\hline Sawa & 7 & $23-40$ & $\begin{array}{l}\text { Alluvial, marble \& } \\
\text { Schist }\end{array}$ & $9-15$ & Anseba-Barka \\
\hline Halhal & 3 & $40,18,9$ & Fractured granite rock & $3.3,0.5,0.6$ & Anseba-Barka \\
\hline Karua & 1 & 34 & Alluvial & Dry well & Eastern low land \\
\hline Afabet & 4 & 47 all & Granite & Poor, $<0.2$ & Eastern low land \\
\hline Mahmimet & 1 & 31 & Alluvial \&granite & 2.2 & Eastern low land \\
\hline Ghed-ghed & 2 & 58,50 & Biotite schist & $3,0.5$ & Eastern low land \\
\hline Wokiro & 2 & 32,30 & Alluvial & $0.8,1.5$ & Eastern low land \\
\hline Emberemi & 1 & 20 & Alluvial & $10 ?$ & Eastern low land \\
\hline Wiaa & 2 & $20,30,24$ & Alluvial fan & $20,26,30$ & Eastern low land \\
\hline Adailo & 3 & $21,28,41$ & Fractured limestone & $8,5,0.5$ & Eastern low land \\
\hline Assab (Harsile) & 18 & $50-60$ & $\begin{array}{l}\text { Alluvial and vesicular } \\
\text { basalt }\end{array}$ & $10-26$ & Eastern low land \\
\hline Ala & 4 & $45,51,52,59$ & Fractured granite & $3.6,4,2.6, \mathrm{dry}$ & Eastern low land \\
\hline Duwaruba & 1 & 60 & $\begin{array}{l}\text { Meta-sediments and } \\
\text { quartz vein }\end{array}$ & 15 & Mereb-Gash \\
\hline Terramni & 1 & 28 & Fractured basalt & 6 & Mereb-Gash \\
\hline Mendefera & 4 & $28,30,70,79$ & Weathered basalt & $0.1,0.2,0.8,2.2$ & Mereb-Gash \\
\hline Halhale & 2 & 30,51 & Fractured basalt & 1,17 & Mereb-Gash \\
\hline Dekemhare & 2 & 53,60 & Weathered granite & $4.2,4$ & Mereb-Gash \\
\hline Hazemo plain & 1 & 104 & Adigrat sandstone & 1.5 & Mereb-Gash \\
\hline Segeneiti & 3 & $40,41,50$ & Fractured granite & $0.1,1,9$ & Mereb-Gash \\
\hline Adi Keih & 2 & 30,40 & $\begin{array}{l}\text { Graphitic schist with } \\
\text { quartz vein }\end{array}$ & 1,7 & Mereb-Gash \\
\hline Senafe & 1 & 40 & Phyllite schist & 1.2 & Mereb-Gash \\
\hline
\end{tabular}

during the summer, June to September) and 'Akeza' or spring rain (the short frequent rainy season during March and April). The remaining months are dry. Rainfall is intense during the period from mid-July to mid-August. The normal average rainfall is shown in the Table1 and the different broad agro- ecological zones are shown in Fig.2. 


\section{Precambrian formation}

The Precambrians are dominant in the central highlands, western lowlands and other parts of the country. These are highly jointed, foliated, fractured, faulted, and weathered. The available bore hold data (Table 2) indicate that these formations can be considered as important aquifers for development of groundwater after selecting feasible locations by hydrogeological and geophysical investigations.

In the northern central highland and western lowland areas of the country (along the Anseba river course, Adobha valley, Sawa river valley and Alebu area of the Gash river valley) large deposits

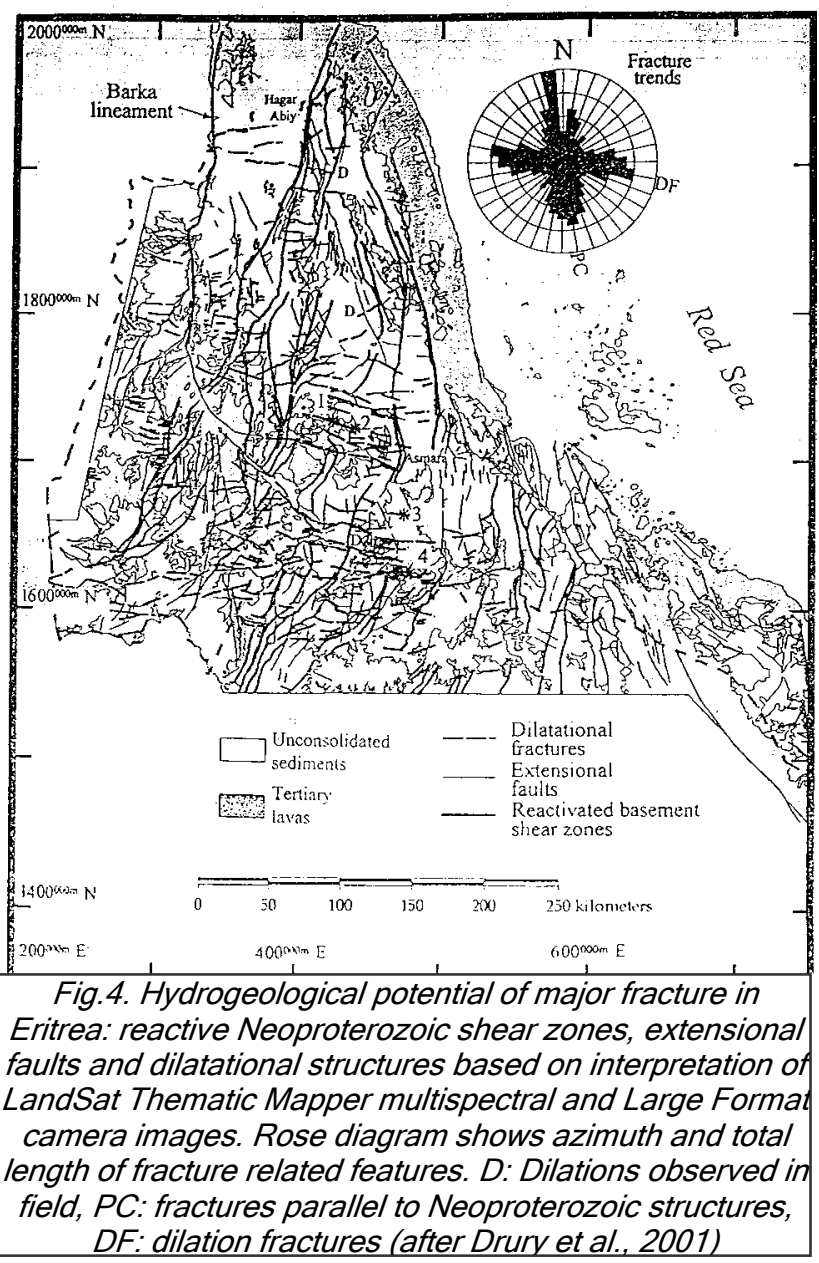

of marble occur. Solution cavities and fracture zones proved to be potential aquifers.

A number of bore wells and dug wells were executed in the Precambrian formations for domestic use in the villages, though they are not so potential for irrigation. However, feasible locations for bore wells can be identified and bore wells can be sunk for promotion of horticulture.

Volcanics

The Tertiary volcanic basalt flows of the Debub region extending from Asmara to Adiquala areas seem to have significant aquifer potential. The main problem with basalt aquifers is the complicated and unpredictable nature of the openings. However some boreholes drilled in basalt aquifers were proved to be potential aquifers. So a detailed study is needed to identify the structural aspects of a formation.

Even though a detailed hydrogeological nature of volcanic rock aquifers in Danakil region is not known, the studies conducted at Harsile well, which is intended for Assab water supply indicate that the vesicular basalt beneath the alluvial deposits is a potential aquifer. In the Danakil region, however, the volcanic rocks receive low recharge due to low precipitation.

Consolidated sedimentary formations (sandstone and limestone)

The sandstone formations in the southern part of the Central Highland (mainly at Kinafina, AdiKeih, Zalambesa and Adailo areas) are well cemented, compact and seem to have a limited capacity of storing and transmitting water. The rocks are less porous and infiltration is low in them. A few boreholes drilled in these strata indicated poor yield aquifers. Sandstones seldom undergo weathering. However, a good soil cover, if there is any, above these rocks is an indication that these rocks underwent sufficient weathering and give rise to aquifers. Detailed integrated hydrogeological and geophysical surveys may help in locating poorly consolidated or unconsolidated sand beds.

Limestone is confined to the southern part of the central highlands and Adailo area of the Danakil region. The bore well data of these formations indicate the possibility of aquifers in solution cavities and fracture zones, though there is the salinity problem.

\section{Soft sedimentary (alluvial) formations}

These formations (fluvial and aeolian), which are dominantly deposited in both the western and eastern lowlands, appear to be the best aquifers in the country. In the eastern lowland, the main aquifers are concentrated along the foot escarpment of the major wadis. Groundwater of this area is greatly affected by high salinity and seawater intrusion (e.g. Wiaa, Emberemi, Shieb area).

The western lowland alluvial deposits (alluvial fans and terraces, colluvial deposits and dunes) are very extensive but thin except along the narrow strips of the major river basins and tributaries. The potential aquifers of these alluvial deposits are confined to the relatively narrow but thick river deposits. There are indications of river basins. The borehole data in these alluvial basins that yield significant groundwater for small to medium scale 
irrigation schemes (Banana plantations for example) indicate these locations are potential aquifers. The western lowlands in general appear to be good aquifers for development of projects (irrigation systems for instance), but detail investigations are needed for identifying prospective aquifers for groundwater development. Drainage

The surface hydrology of Eritrea is shown in Fig.3. There are five clearly divided major river basins. They are: 1) The Setit (Tekeze) river basin, 2) the Mereb-Gash river basin, 3) the AnsebaBarka river basin 4) the Red Sea basins and 5) the Danakil basin.

Except the Setit all other rivers and their tributaries are seasonal and intermittent. No hydrometric records are available for the rivers within the country. The average annual discharge for the Mereb-Gash at Kassala over the years 1907 to 1929 is $430^{*} 10^{\wedge} 6 \mathrm{cu}$ m. (Zerai, 1996)

Structural Units

The country is crisscrossed by different linear structures like foliations, joints, shears, faults, dilatational structures, etc. Drury et al. (2001) carried out a regional systematic study about the hydrogeological potential of the major fractures in Eritrea as shown in the Fig.4.

Drury et al. (1994) by their study of Landsat and large format camera images identified N-S / NNESSW, NW-SENNW-SSE and E-W to WNW-ESE tending linear features. They described the NW-SE trending lineaments as active strike-slip faults with dextral movements and related them to the neotectonic structures in the Red Sea. According to Ghebreab (1998), the N-S, NW-SE and NNWSSE trending fractures represent normal faults with variable dip to either side of the major strikes. Some of them with very large throws around of around $2.2 \mathrm{~km}$ gave rise to the Red Sea escarpment (Drury et al., 1994). According to Drury et al. (1994, 2001)), the linear fractures trending E$\mathrm{W}$ are considered as sets of post-Precambrian structures representing a regional N-S dilation restricted to the main axis of Tertiary uplift and the western flanks of the Red Sea rift; and the normal faults parallel to this trend suggest that some structures are related in age to the Red Sea evolution.

The predominant dyke swarms have the orientations of NNE-SSW, NNW-SSE, NW-SE and ENE- SSW. Drury et al. (1994) ascribed the NNESSW trending swarm dykes that parallel the steep westerly dipping basement fabric to the Tertiary tectonic evolution. Mohr (2001) felt that the eruption took advantage of the regional structural grain of the basement schists / gneisss. NNW-SSE and NW-SE trending dykes were described as Red
Sea rift related structures (Drury et al. 1994, Talbot \& Ghebreab 1997; Ghebreab, 1998).

Even the basement rocks comprising schists and gneisses are highly foliated to a great extent. Also these formations are deeply weathered. These structural features and their intensity favour groundwater movement and storage.

\section{Discussion and conclusion}

The occurrence of groundwater in any region is largely controlled by the prevalence and of primary and secondary porosity. Groundwater exploration entails study, delineation and mapping of different lithological, morphological and structural units, at regional as well as local scale. These data show major rock types, different river basins, distribution of rainfall and structural features such as folds, faults, lineaments, fractures and dyke systems and these aspects are to be closely scrutinized to decide whether a region is hydrogeologically potential.

The Geology of the area and the structural lineaments suggest that the rock types of Eritrea form suitable conduits and receptacles of groundwater. Besides the alluvial deposits along the watercourses, the abandoned and buried valleys, the plains and the intermontane valleys are good reservoirs of groundwater. Because there are no perennial rivers or standing water bodies (except the Setit and a few reservoirs), Eritrea has to depend mostly on groundwater to meet the water requirements of the people. Exploration for feasible locations of ground water has to be made, ground water has to be exploited by drilling boreholes to proper depths, and properly developed.

Management also has to be carried out by taking up measures for replenishing the subsurface aquifers by community based watershed development programs with focus on rainwater harvesting. According to Murthy (1998), a watershed is "an integrated approach to replenish surface water, recharge groundwater, rejuvenate base flow, arrest soil erosion, restore soil condition, regenerate soil fertility, raise biomass production, redouble crop production and revive rural riches". Watershed management involves construction of artificial structures like gully plugging, contour trenching and bunding, plantations on the trenches and bunds, rock fill dams, check dams, grass waterways and such. These measures are useful not only to replenish the subsurface aquifers but also to check soil erosion. It is understood that an increase in velocity of runoff current by two times leads to twenty times increase in soil carrying capacity (Subba Rao, 2000). So water harvesting is as important as prevention of runoff and thereby the soil erosion. 
Development and management of groundwater in the country are to be carried out in a twopronged way. While one is centralized, broad based and on regional scale the other is decentralized and confined to isolated villages. They are to be carried out separately and simultaneously.

In the regional scale, development and management have to be taken up step by step. First, it has to be carried out in the GBZ and CRZ zones where the rainfall is maximum and the density of population is more; in the second phase the WEZ has to be taken up and in the third phase the northwestern lowlands zone has to be developed. Lastly these programs are to be extended to the coastal plains zone and the Danakel depression zone.

The author has visited the country to a reasonable extent and studied the morphological as well as geological units and hydrogeology. He had access to some of the wells and bore wells in the city of Asmara. The water table in the open well in the University of Asmara is hardly $5 \mathrm{~m}$ below ground level. All the open wells in the vegetable fields on the right side of the road from Sembel residential complex to the airport show very shallow water table, which is always hardly three meter below the ground level. Also around Asmara, there are a few ponds that contain water in all the seasons.

The study of geology and hydrogeology indicate that Eritrea is bestowed with potential aquifers to meet the water requirements of the country. These groundwater resources have to be developed and managed on the basis of community based watershed development programs with focus on rainwater harvesting.

\section{Acknowledgements}

The author has drawn information from different sources and he gratefully acknowledges all of them.

\section{References}

1. Abul Haggag $Y$ (1961) A Contribution to the Physiography of Northern Ethiopia, University of London, Athlone Press.

2. Berhe SM (1991) Tectonic Evolution of PanAfrican Mozambique Belt in NE and E Africa: Extended Abstract International field Geotraverse/Workshop through the Mozambique Belt, Tanzania, July 23- August 6, 1991.

3. Drury SA, Kelley SP, Berhe SM, Collier RE and Abraham M (1994) Structures Related to Red Sea evolution in northern Eritrea. Tectonics. 13, 1371- 1380.
4. Drury SA, Peart RJ and Deller MEA (2001) Hydrogeological potential of major fractures in Eritrea. J. Afr. Earth Sci. 32 (2) 163-177.

5. Gajendran N (2007a) Endangered coral islands: A case study of Dahlak in Red Sea. Indian J.Sci. Technol. 1 (1), 1-10. Domain site: http://www.indjst.org.

6. Gajendran N (2007b) Eritrea Institute of Technology: an innovative centre imparting knowledge and discipline. Indian J.Sci. Technol. 1 (1), 1-2. Domain site: http://www.indjst.org.

7. Ghebreab W (1998) Tectonics of the Red Sea region reassessed. Earth Science Rev. 45, 145.

8. Holmes A (1951) The sequence of Precambrian Orogenic Belts in South and Central Africa. $18^{\text {th }}$ Int. Geol. Congr. London, 1948, 4, pp: 254- 269.

9. Krishna Rao S (2007) Early man and his culture from Eritrea in Northeast Africa. Indian J.Sci. Technol. 1 (2), 1-8. Domain site: http://www.indjst.org.

10. Mohr P (2001) The Asmara dyke swarms, Eritrean plateau: Physical parameters of an offrift olivine dolerite injection zone. Unpul. Manuscript, University of Asmara, Eritrea.

11. Murthy JVS (1998) Watershed Management, Newage International Public, New Delhi.

12. Ravinder Rena (2007) Educational breakthrough in Eritrea: some expectations and outcomes. Indian J.Sci. Technol. 1 (1), 112. Domain site: http://www.indjst.org.

13. Subba Roa C (2000) Watershed Development, Association of Hydrologists of India, Visakhapatnam, India.

14. Talbot CJ and Ghebreab W (1997) Red Sea detachment and basement core complexes in Eritrea. Geology, 25 (7), 655- 658.

15. Vail JR (1987) Late Proterozoic terrains in the Arabian- Nubian Shield and their characteristic mineralization. Geol. J. 22, 161-175.

16. Zerai H (1996) Groundwater and geothermal resources of Eritrea with the emphasis on their chemical quality. J. Afr. Earth Sci. 22 (4) 415421. 